\title{
Effect of Feed and Draught on Carbon Dioxide Emission from the Rumen of He-Buffalo
}

\author{
Akanksha*, Jayant Singh and T.P. Singh \\ Department of Farm Machinery and Power Engineering, College of Technology, GBPUA\&T, \\ Pantnagar, Uttarakhand, 263145, India \\ *Corresponding author
}

\begin{tabular}{|l|}
\hline Ke y w o r d s \\
Trifolium \\
Alexandrinum \\
(Berseem), \\
Treadmill, He- \\
buffalo, $\mathrm{CO}_{2}$ \\
concentration, \\
Bhusa, Draught
\end{tabular}

A B S T R A C T

The bacteria in ruminant animals help to digest the food and produce copious amounts of carbon dioxide and methane in the process. So, to know the effect of feed on $\mathrm{CO}_{2}$ emission from rumen of he-buffalo the study was conducted at 4 different feed concentration at two different draught levels at 3 hour of exercise on treadmill having speed of $2 \mathrm{~km} / \mathrm{h}$ and 3 hour of rest period under maintained environment controlled chamber. The environment temperature and relative humidity was maintained according to the average temperature and relative humidity of the area which was $25^{\circ} \mathrm{C}$ and $90 \%$. Two draught levels of $10 \%$ and $12 \%$ of body weight were selected. The study shows decreasing $\mathrm{CO}_{2}$ concentration in exhaled air of test he-buffalo with increase in duration of exercise and also with increase in level of draught and it shows increasing trend with the increase of berseem percentage in feed. The maximum concentration of $\mathrm{CO}_{2}$ is $75.60 \%$ at $10 \%$ draught level and at $75 \%$ berseem concentrated feed on dry matter basis during initial hour (o h) of exercise. Minimum concentration observed is $69.77 \%$ at $12 \%$ draught level after $3^{\text {rd }} \mathrm{h}$ of exercise and when $100 \%$ wheat bhusa on dry matter basis was used as feed. $\mathrm{CO}_{2}$ concentration of test he-buffalo shows increasing trend with increase in duration of rest. The maximum concentration of carbon dioxide is $76.59 \%$ which is at $10 \%$ draught (at 3rd hour of rest period) and at $75 \%$ berseem concentrated feed on dry matter basis. Minimum concentration observed is $72.26 \%$ at $12 \%$ draught level after 1 st hour (initial hour) of rest and at $100 \%$ wheat bhusa on dry matter basis was used as feed.

\section{Introduction}

Global warming has attracted the attention of the world communities in the recent years due to occurrence of the numerous abnormal weather events, rise in sea level, displacement of communities, and drop in agricultural productivity and its effect on livestock and farming. The effects of the global livestock industry on global warming have been studied for more than three decades and its effects were well documented. Different studies show that the feeding habits of cattle - cows, buffaloes and all ruminant creatures contributes to climate change. A buffalo is a ruminant animal, which means it extracts nutrition from the food that it eats by fermentation process. Agriculture sector accounts for highest anthropogenic GHGs emissions. The United Nations Environment 
Programme (UNEP) analysis that the world's cattle contributed to more greenhouse gas emissions than global transport report was released in 2006. It was estimated that 21$25 \%$ of carbon dioxide $\left(\mathrm{CO}_{2}\right)$ from agriculture activities contributes to the anthropogenic GHGs emissions (Angela et al., 2000). The animal emits $\mathrm{CO}_{2}$ per day because of bacterial digesting cellulose in the Rumen mainly herbivores. Buffaloes contribute to nearly $21.23 \%$ (108.7 million) of the total livestock population in India with its population growth of $4.18 \%$ in rural areas (Shown in the below chart). Total buffaloes population in India is 108.7 million. In Uttarakhand, buffaloes numbered at $9,87,775$ as per 2012 Census.

Nearly $60 \%$ of its population is dependent on agriculture and allied activities and the draught animal are primary source of power in India in particular and developing countries in general. Hence, the present study was designed to evaluate carbon dioxide emission from rumen of he-buffalo with the effect of feed and draught levels at different exercise and rest periods.

\section{Materials and Methods}

The present study has been conducted from October 2016 to April 2017 in the Department of Farm Machinery and Power Engineering, College of Technology, G.B. Pant University of Agriculture and Technology, Pantnagar. The study fully based on the guidelines of the Committee for the Purpose of Control and Supervision of Experiments on Animals (CPCSEA, 2006). The he-buffalo was maintained on wheat bhusa, berseem and concentrate in different proportion for the present study.

\section{Study site and experimental design}

For the study, a psychometric chamber was developed. The site lies in Terai region of
India at $283.8 \mathrm{~m}$ above mean sea level, $29^{\circ} \mathrm{N}$ latitude, $29.3^{\circ} \mathrm{E}$ longitude. The psychometric chamber was developed in the Department. The chamber having animal tread mill, humidifiers, air conditioners (split type), thermometer, etc. Temperature and humidity was maintained as $25 \pm 1^{\circ} \mathrm{C}$ and $90 \pm 1 \%$ respectively. Two draught $10 \%$ and $12 \%$ of body weight of the he-buffalo were selected. The he-buffalo was put to exercise on treadmill for 3 hours continuously followed by 3 hours of rest. The samples were collected every hour starting from $0 \mathrm{hr}$ in Douglas bag. Speed and inclination of the treadmill were fixed at $2 \mathrm{~km} / \mathrm{h}$ and $0^{\circ}$ respectively throughout the study. Pant adjustable single animal collar harness with U-shaped pipe frame for supporting draught used for harnessing of buffalo.

\section{Selection of animal and fodder for the experiment}

Two murrah he-buffaloes weighing $550 \pm 18$ $\mathrm{Kg}$, age 5-6 year have been selected for the experiment and were maintained on wheat bhus, green fodder (berseem) at fixed rate of $3 \mathrm{~kg} / 100 \mathrm{~kg}$ body weight per day on dry matter basis along with fixed concentrate amount of $2.5 \mathrm{~kg} /$ day for each trial.

The dietary treatment was given in different composition of threshed wheat straw (length=1.5-3.2cm), berseem (length= 3-4 $\mathrm{cm})$, concentrate and water. Wheat straw has an average of 8.5 to $15 \%$ lignin and 70 to 80 $\%$ fiber, its dry matter content was $92.11 \mathrm{~g}$ per $100 \mathrm{~g}$ of wheat straw. In $100 \mathrm{~g}$ of berseem total 60-65\% digestible nutrient, $17 \%$ crude protein and $25.9 \%$ crude fiber and its dry matter content was $8.85 \mathrm{~g}-12.65 \mathrm{~g}$. Amount of concentrate was fixed as $2.5 \mathrm{~kg}$ on daily basis for each trial. Feed were weighed on dry matter intake (DMI) before the experiment. Body weights were measured every seven days. 


\section{Daily feed for different trials conducted}

Berseem and wheat bhusa was used as feed. Berseem is a highly palatable fodder. Different amount of feed is selected for different trials. The wheat bhusa and berseem diets were offered twice daily at 08:00am and 06:00pm.

$\mathrm{T}_{1}=2.5 \mathrm{~kg}$ concentrate $+16 \mathrm{~kg}$ wheat straw per day.

$\mathrm{T}_{2}=2.5 \mathrm{~kg}$ concentrate $+12 \mathrm{~kg}$ wheat straw + $28 \mathrm{~kg}$ berseem per day.

$\mathrm{T}_{3}=2.5 \mathrm{~kg}$ concentrate $+8 \mathrm{~kg}$ wheat straw + $56 \mathrm{~kg}$ berseem per day.

$\mathrm{T}_{4}=2.5 \mathrm{~kg}$ concentrate $+4 \mathrm{~kg}$ wheat straw + $75 \mathrm{~kg}$ berseem per day.

Feeding was done on dry matter basis during the period of 14 days continuously and then the buffalo was made to exercise on tread mill for four numbers of days.

\section{Buffalo on treadmill exercise}

The he-buffalo were exercised on treadmill from morning 10:00 am to afternoon 01:00 $\mathrm{pm}$, for a period of three hours or up to the he-buffalo reached a stage of fatigue (fatigues score card was referred to diagnose). After that the buffalo kept for rest for three hours from 01:00 pm to 04:00 pm in controlled chamber. For the analysis $\mathrm{CO}_{2}$ production by he- buffalo the exhaled gas samples were taken on hourly basis during exercise and rest periods of 3 hours for four no of days in each trial.

\section{Carbon dioxide measurement technique}

Samples was collected by placing an air tight face mask on the mouth of he-buffalo which was connected with the leak proof Douglas bag as shown in figure 1 to collect and store the exhaled gas. A $22 \mathrm{~mm}$ diameter anti-static corrugated rubber tube and a three way non return valve used to connect the face mask with Douglas bag. Sample for analysis were collected with the help of $20 \mathrm{ml}$ disposable syringes. The collected sample was analyzed through Gas Chromatograph technique. Sample was analyzed using propaq Q column in Thermal Conductivity Detector of Nucon 5700 Gas Chromatograph in Bio-Mechanics lab of Farm Machinery and Power Engineering Department. Hydrogen gas was used as carrier gas for the analysis. Volume of sample used for analysis was $2 \mathrm{ml}$.

\section{Experimental design and data analysis}

The Design Expert 10 Software was used for the data analysis. The experiment was designed in factorial, multilevel categorical method completely randomized design. For the analysis of data ANOVA technique using F-test at 1\%, 5\% and 10\% level of significance was used. For each dependent parameters with different combinations of independent variables at constant temperature, humidity, speed and inclination of treadmill the linear regression analysis technique was used to develop mathematical modelling using Design Expert 10 software.

\section{Results and Discussion}

Effect of different influencing factors i.e. different type of feeds, draughts and duration of exercise on the presence of carbon dioxide gas concentration in the collected exhaled air of he-buffalo was estimated and statistically analysed.

Figure 3.1 to 3.6 shows the average $\mathrm{CO}_{2}$ concentration observed during the treadmill exercise at two draught levels, 4 feed levels at $3 \mathrm{~h}$ of exercise and $3 \mathrm{~h}$ of rest period at constant treadmill speed and maintained 
environment controlled chamber. Increase and decrease was measured with respect to $0 \mathrm{hr}$.

\section{$\mathrm{CO}_{2}$ concentrations observed during exercise}

The maximum concentration of $\mathrm{CO}_{2}$ is 75.60 $\%$ at $10 \%$ draught level and at $75 \%$ berseem on dry matter basis during initial hour $(0 \mathrm{~h})$ of exercise. Minimum concentration observed is $69.77 \%$ at $12 \%$ draught level after $3^{\text {rd }} \mathrm{h}$ of exercise and at $100 \%$ wheat bhusa on dry matter basis was used as feed. It was observed that maximum percentage decrease in $\mathrm{CO}_{2}$ concentration is 4.03 which were at $12 \%$ draught and at feed proportion of $100 \%$ bhusa on dry matter basis. The minimum percentage decrease found is $1.32 \%$ at $10 \%$ draught level and $75 \%$ berseem proportion on dry matter basis was used for feeding purpose. Decrease in $\mathrm{CO}_{2}$ concentration was found 2.71 and 4.03 percent at $10 \%$ and $12 \%$ draught levels respectively when $100 \%$ wheat bhusa on dry matter basis was used as feed. When addition of $25 \%$ berseem was done on dry matter basis the percentage decrease in $\mathrm{CO}_{2}$ concentration was observed is 2.54 and 3.87 percent at $10 \%$ and $12 \%$ draught. Similarly, 1.72 and 2.85 percent decrease was observed at $10 \%$ and $12 \%$ draught when $50 \%$ berseem on dry matter basis was added in feed. Percentage decrease of 1.32 and 2.14 percent is observed at $10 \%$ and $12 \%$ draught respectively when $75 \%$ berseem on dry matter basis used in feed.

\section{$\mathrm{CO}_{2}$ concentrations observed during rest}

The maximum concentration of carbon dioxide is $76.59 \%$ which is at $10 \%$ draught and having $75 \%$ berseem concentration on dry matter basis at $3^{\text {rd }}$ hour of rest period. Minimum concentration observed is $72.26 \%$ at $12 \%$ draught level after $1^{\text {st }}$ hour (initial hour) of rest and when $100 \%$ wheat bhusa on dry matter basis was used as feed. During the study the maximum $\mathrm{CO}_{2}$ concentration was found $75.60 \%$ during initial hour and $76.59 \%$ at $3^{\text {rd }} \mathrm{h}$ of rest which was slightly higher than the $65.5 \%$ which was found by Sniffen and Herdt (1991) during investigation on dairy cattle.

It is observed that maximum percentage increase in $\mathrm{CO}_{2}$ concentration is $2.32 \%$ after third hour of rest from the initial ( 0 hour) which is at $10 \%$ draught level and at feed level of $100 \%$ bhusa on dry matter basis. The minimum percentage increase found is $0.88 \%$ from the initial $(0 \mathrm{~h})$ at $12 \%$ draught level, $75 \%$ berseem on dry matter basis was used for feeding purpose. Percentage increase in $\mathrm{CO}_{2}$ was found 2.32 and 1.86 percent from initial at $10 \%$ and $12 \%$ draught level respectively at $100 \%$ bhusa on dry matter basis used as feed. At addition of $25 \%$ berseem in feed on dry matter basis the percentage increase observed is 1.30 and 1.03 percent at $10 \%$ and $12 \%$ draught level. Similarly, increase of 1.40 and 1.39 percent from initial was observed at $10 \%$ and $12 \%$ draught at the addition of $50 \%$ berseem in feed on dry matter basis. Percentage increase of 1.31 and 0.88 percent from initial is observed at $10 \%$ and $12 \%$ draught respectively when $75 \%$ berseem on dry matter basis was used in feed.

Average percentage increase from $3^{\text {rd }}$ hour of exercise to the first hour rest period was found between 1 to $4 \%$. The maximum percentage increase in $\mathrm{CO}_{2}$ concentration after exercise and at first hour of rest was 3.44 at feed level of $100 \%$ bhusa on dry matter basis at $12 \%$ draught and minimum was 1.58 at feed concentration of $75 \%$ berseem on dry matter basis at $10 \%$ level of draught.

The concentration of $\mathrm{CO}_{2}$ at $3^{\text {rd }} \mathrm{h}$ of rest period after exercise was higher than the initial $(0 \mathrm{~h})$. The relationship between $\mathrm{CO}_{2}$ concentration with different feed level, 
duration of exercise, duration of rest period after exercise, two draught levels at constant level of temperature, humidity, inclination of treadmill and speed is depicted in Figure 3.13.6 represent the average relation between different feed concentration and $\mathrm{CO}_{2}$ emission at different duration of exercise and rest period at $10 \%$ and $12 \%$ draught.

\section{Results of regression analysis of data obtained during exercise}

The regression analysis of the experimental variables for carbon dioxide was done using multilevel categorical design in Factorial method of Design expert 10. Thirty two experiments were carried out with the combinations of three variables and there different levels. The F-value of model obtained implies that the model was significant at $1 \%$ level $(\mathrm{p}<0.01)$ of significance.

\section{Statistical analysis of $\mathrm{CO}_{2}$ concentration during exercise}

In terms of linear, interactive and quadratic term the effect of different treatment on $\mathrm{CO}_{2}$ emission was done through Analysis of Variance (ANOVA). F-value indicate that linear terms of independent variables significantly affected $\mathrm{CO}_{2}$ concentration $(\mathrm{P}<0.01)$ at $1 \%$ level of significance. F-value of individual independent parameters indicate that effect of draught, feed, duration of exercise was highly significant at $1 \%$ level of significance $(p<0.0001)$ (Table 1$)$.

\section{Numerical analysis of $\mathrm{CO}_{2}$ concentration in} exhaled gas of buffalo during exercise

Multiple linear regression analysis was done for the $\mathrm{CO}_{2}$ concentration in exhaled gas. Regression analysis results that the coefficient of determination $\left(\mathrm{R}^{2}\right)$ for regression model is 0.9879 , which conclude that the model was valid for $98.79 \%$ data. The value of $\mathrm{R}^{2}-$ adjusted was 98.37 which was observed to be close to $\mathrm{R}^{2}$ (0.9879) value. It shows a relatively satisfactory adjustment to the model obtained from the experimental data.

The predicted $R^{2}(0.9796)$ is in reasonable agreement with the adjusted $\mathrm{R}^{2}$ of 0.9837 i.e., the difference is less than 0.2. The Model obtained was highly significant $(\mathrm{p}<0.01)$ at $F_{\text {cal }}$ value of 205.00 which was greater than $F_{\text {tab }}$ value 9.23 at $1 \%$ level of significance.

The significant predicted quadratic regression equation for $\mathrm{CO}_{2}$ emission in exiled gas of hebuffalo is as follows:

$\mathrm{CO}_{2}$ concentration $(\%) \mathrm{Y}=73.62-0.29 \mathrm{~A}+$ $1.66 \mathrm{~B}-0.99 \mathrm{C}-0.22 \mathrm{AC}+0.32 \mathrm{BC}-0.42$ $\mathrm{B}^{2}$

Where,

$\mathrm{A}=$ Draught

$\mathrm{B}=$ Feed $(\% \mathrm{DMB}$ of berseem $)$

$\mathrm{C}=$ Duration of exercise and rest $(\mathrm{h})$

Positive terms of coefficient $\mathrm{B}, \mathrm{AB}, \mathrm{BC}$ indicate the increase in $\mathrm{CO}_{2}$ concentration with increase in level of variables. Negative term of coefficient $\mathrm{A}, \mathrm{C}, \mathrm{AC}, \mathrm{B}^{2}$ indicate the decrease in $\mathrm{CO}_{2}$ concentration with increase in level of variables.

\section{Graphical analysis of $\mathrm{CO}_{2}$ concentration in exhaled gas during exercise}

The method used for the graphical analysis of data obtained during the experiment was Factorial method multi categorical design in Design Expert 10. Figure 3.7 gives the 3Dimensional representation of the relationship between the independent variables and the $\mathrm{CO}_{2}$ emission during exercise it was concluded from graph the decrease of $\mathrm{CO}_{2}$ emission with increase in draught and 
duration of exercise and increasing trend with increase in berseem percentage.

\section{Results of regression analysis of data obtained during rest}

The regression analysis of the experimental variables was done using multilevel categorical design with three variables in the Factorial method. Twenty four experiments were carried out with the combinations of three variables containing different levels. The model F-value implies the model was significant at $1 \%$ level $(\mathrm{p}<0.01)$ of significance.

\section{Statistical analysis of $\mathrm{CO}_{2}$ concentration in exhaled gas during rest}

Shows the effect of different treatment variables in linear, interactive and quadratic term on $\mathrm{CO}_{2}$ emission during rest. In Table Fvalue (68.66) indicate that linear terms of independent variables significantly affected $\mathrm{CO}_{2}$ concentration $(\mathrm{P}<0.01)$ at $1 \%$ level of significance. The interactive and quadratic term also affect $\mathrm{CO}_{2}$ concentration at $1 \%$ level of significance. It was found that the effect of draught, feed, duration of exercise was highly significant at $1 \%$ level of significance $(\mathrm{p}<0.0001)$.

\section{Numerical analysis of $\mathrm{CO}_{2}$ concentration in exhaled gas of buffalo}

Multiple linear regression analysis was done for the $\mathrm{CO}_{2}$ concentration in exiled gas at rest. The Regression analysis results that the coefficient of determination $\left(\mathrm{R}^{2}\right)$ for regression model is 0.9765 , which conclude that the model was valid for $97.65 \%$ data.

The value of $\mathrm{R}^{2}$-adjusted was 0.9639 which was observed to be close to $R^{2}(0.9765)$ value. It shows a relatively satisfactory adjustment to the model obtained from the experimental data. The predicted $\mathrm{R}^{2}(0.9533)$ is in reasonable agreement with the adjusted $R^{2}$ of 0.9765 i.e., the difference is less than 0.2. The Model obtained was highly significant $(p<0.01)$ at $F_{c a l}$ value of 68.66 which was greater than $\mathrm{F}_{\text {tab }}$ value 3.89 at $1 \%$ level of significance.

The significant predicted quadratic regression equation developed for $\mathrm{CO}_{2}$ emission in exiled gas of he- buffalo is given below.

$\mathrm{CO}_{2}$ concentration $(\%) \mathrm{Y}=75.08-0.31 \mathrm{~A}+$ $1.19 \mathrm{~B}+0.61 \mathrm{C}-0.19 \mathrm{BC}-0.18 \mathrm{~B}^{2}$. .. (3.2)

Where,

$\mathrm{A}=$ Draught

$\mathrm{B}=$ Feed $(\mathrm{kg})$

$\mathrm{C}=$ Duration of exercise and rest $(\mathrm{h})$

Positive terms of coefficient $\mathrm{B}, \mathrm{C}$ indicate the increase in $\mathrm{CO}_{2}$ concentration with increase in level of variables. Negative term of coefficient $\mathrm{A}, \mathrm{BC}, \mathrm{B}^{2}, \mathrm{C}^{2}$ indicate the decrease in $\mathrm{CO}_{2}$ concentration with increase in level of variables.

\section{Graphical analysis of $\mathrm{CO}_{2}$ concentration in exhaled gas during rest}

The Factorial method multilevel categorical design in Design Expert 10 was used for the graphical analysis of data obtained during the experiment when buffalo was at rest after exercise.

Figure 3.8 gives the 3-Dimensional representation of the relationship between the independent variables and the $\mathrm{CO}_{2}$ emission during rest period after exercise. It was concluded from graph the decrease of $\mathrm{CO}_{2}$ emission with increase in draught and increase in emission with increase in duration of exercise and berseem percentage of feed. 
Table.1 Dependent and independent variables

\begin{tabular}{|c|c|c|c|c|c|c|c|c|}
\hline \multicolumn{8}{|c|}{ Independent Variables } & \multirow{2}{*}{$\begin{array}{c}\text { Dependent } \\
\text { variable }\end{array}$} \\
\hline \multirow[t]{2}{*}{$\begin{array}{c}\text { Trial } \\
\text { no. }\end{array}$} & \multicolumn{3}{|c|}{ Feed composition } & \multicolumn{2}{|c|}{$\begin{array}{c}\text { Draught } \\
\text { equivalen } \\
\text { t to } \% \\
\text { body } \\
\text { weight }\end{array}$} & \multirow[t]{2}{*}{\begin{tabular}{|c|}
$\begin{array}{c}\text { Sample } \\
\text { collection at } \\
\text { different } \\
\text { hours of } \\
\text { exercise }\end{array}$ \\
hour
\end{tabular}} & \multirow[t]{2}{*}{$\begin{array}{c}\text { Sample } \\
\text { collection } \\
\text { at different } \\
\text { hours of } \\
\text { rest } \\
\text { hour }\end{array}$} & \\
\hline & $\begin{array}{l}\text { Wheat } \\
\text { straw } \\
(\%)\end{array}$ & $\begin{array}{c}\text { Berseem } \\
(\%)\end{array}$ & $\begin{array}{l}\text { Concentrate } \\
\text { (fixed) }\end{array}$ & $\%$ & $\%$ & & & $\begin{array}{c}\text { Percentage } \\
(\%)\end{array}$ \\
\hline $\mathbf{T}_{1}$ & 100 & 0 & $2.5 \mathrm{~kg}$ & 10 & 12 & $0^{\text {th }}, 1^{\text {st }}, 2^{\text {rd }}$ rd and & $\begin{array}{c}4^{\text {th }}, 5^{\text {th }} \text { and } \\
6^{\text {th }}\end{array}$ & $\begin{array}{c}\mathrm{CO}_{2} \\
\text { production }\end{array}$ \\
\hline $\mathbf{T}_{2}$ & 75 & 25 & $2.5 \mathrm{~kg}$ & 10 & 12 & $0^{\text {th }}, 1^{\text {st }}, 2^{\text {rd }}$ and & $4^{\text {th }}, 5^{\text {th }}$ and & $\begin{array}{c}\mathrm{CO}_{2} \\
\text { production }\end{array}$ \\
\hline $\mathbf{T}_{\mathbf{3}}$ & 50 & 50 & $2.5 \mathrm{~kg}$ & 10 & 12 & $\begin{array}{l}0^{\text {th }}, 1^{\text {st }}, 2^{\text {rd }} \\
\text { and } 3^{\text {rd }}\end{array}$ & $\begin{array}{c}4^{\text {th }}, 5^{\text {th }} \text { and } \\
6^{\text {th }}\end{array}$ & $\begin{array}{c}\mathrm{CO}_{2} \\
\text { production }\end{array}$ \\
\hline $\mathbf{T}_{4}$ & 25 & 75 & $2.5 \mathrm{~kg}$ & 10 & 12 & $\begin{array}{l}0^{\text {th }}, 1^{\text {st }}, 2^{\text {rd }} \\
\text { and } 3^{\text {rd }}\end{array}$ & $\begin{array}{c}4^{\text {th }}, 5^{\text {th }} \text { and } \\
6^{\text {th }}\end{array}$ & $\begin{array}{c}\mathrm{CO}_{2} \\
\text { production }\end{array}$ \\
\hline
\end{tabular}

Fig.1.1 Distributions of all India Livestock census-2012

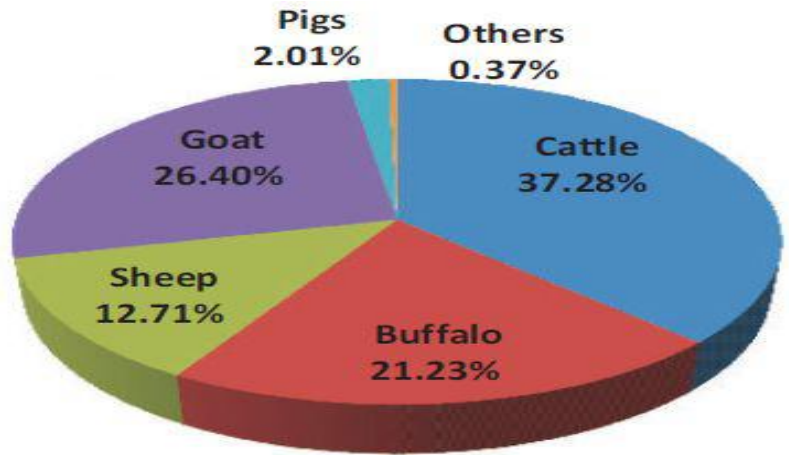

Fig.2 View of three way air valve and face mask connected with Douglas bag
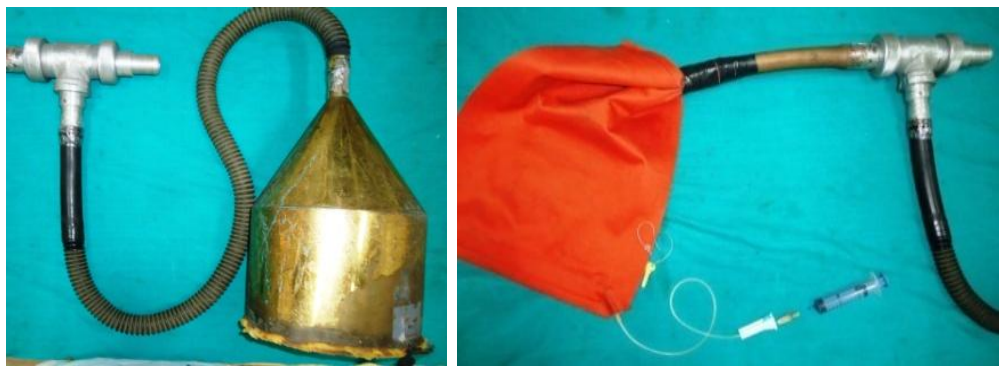
Fig.3.1 Relationship between $\mathrm{CO}_{2}$ concentrations in the exhaled gas during exercise and rest at two draught levels and at $100 \%$ wheat bhusa on DMB as feed
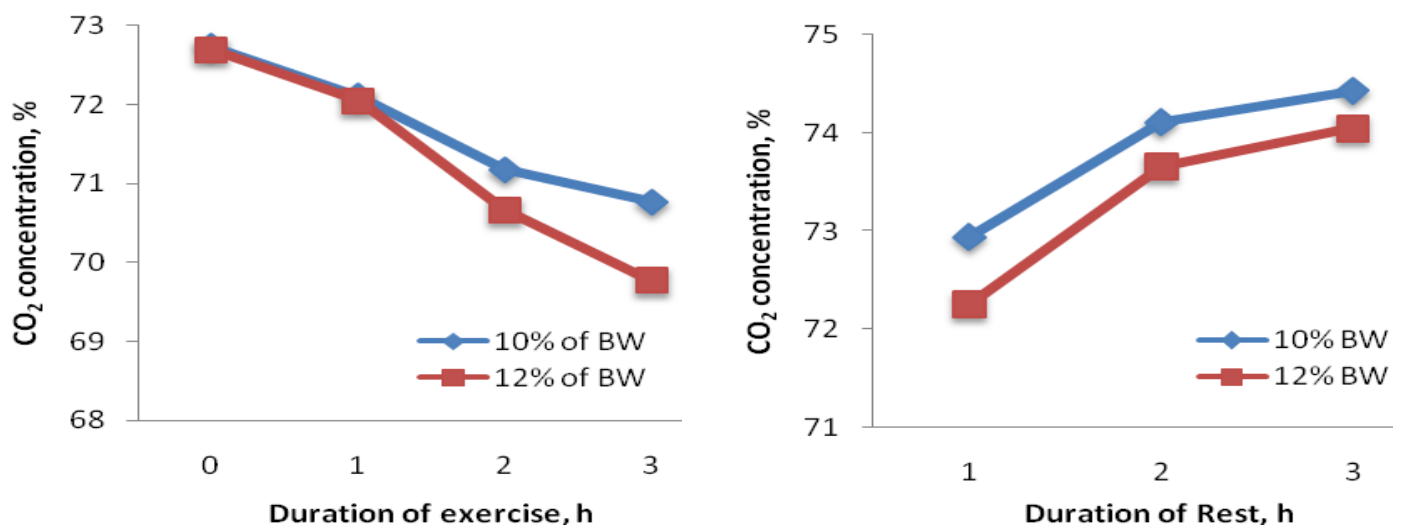

Fig.3.2 Relationship between $\mathrm{CO}_{2}$ concentrations in the exhaled gas during exercise and rest at two draught levels and at $25 \%$ berseem on DMB as feed
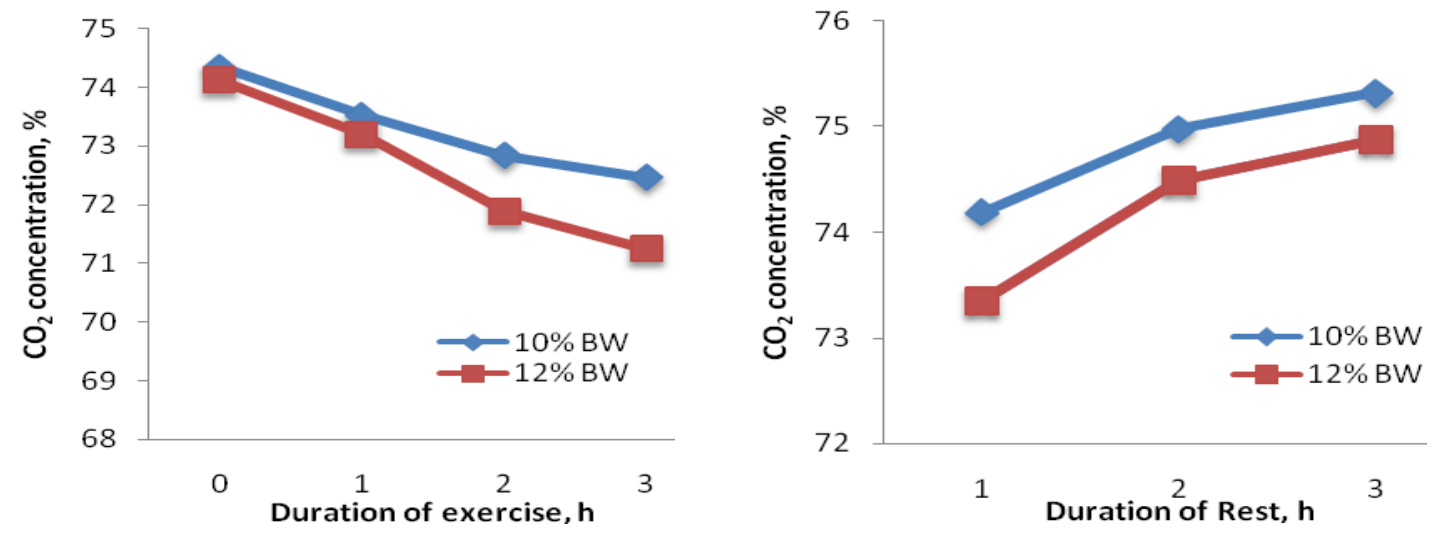

Fig.3.3 Relationship between $\mathrm{CO}_{2}$ concentrations in the exhaled gas during exercise and rest at two draught levels and at $50 \%$ berseem on DMB as feed
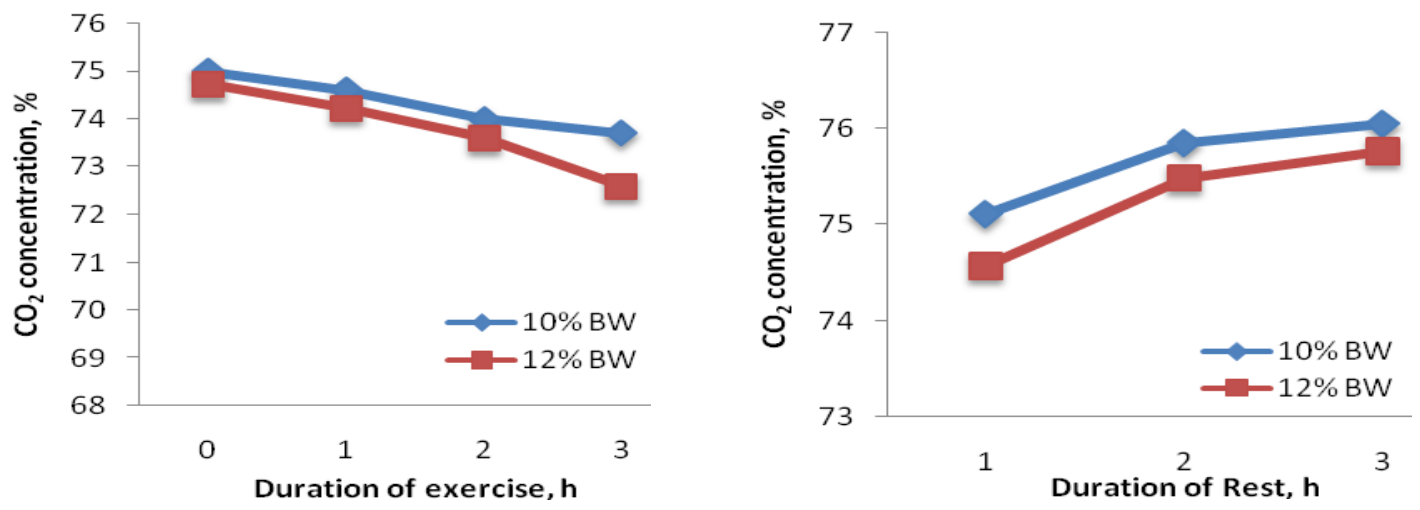
Fig.3.4 Relationship between $\mathrm{CO}_{2}$ concentrations in the exhaled gas during exercise and rest at two draught levels and at $75 \%$ berseem on DMB as feed
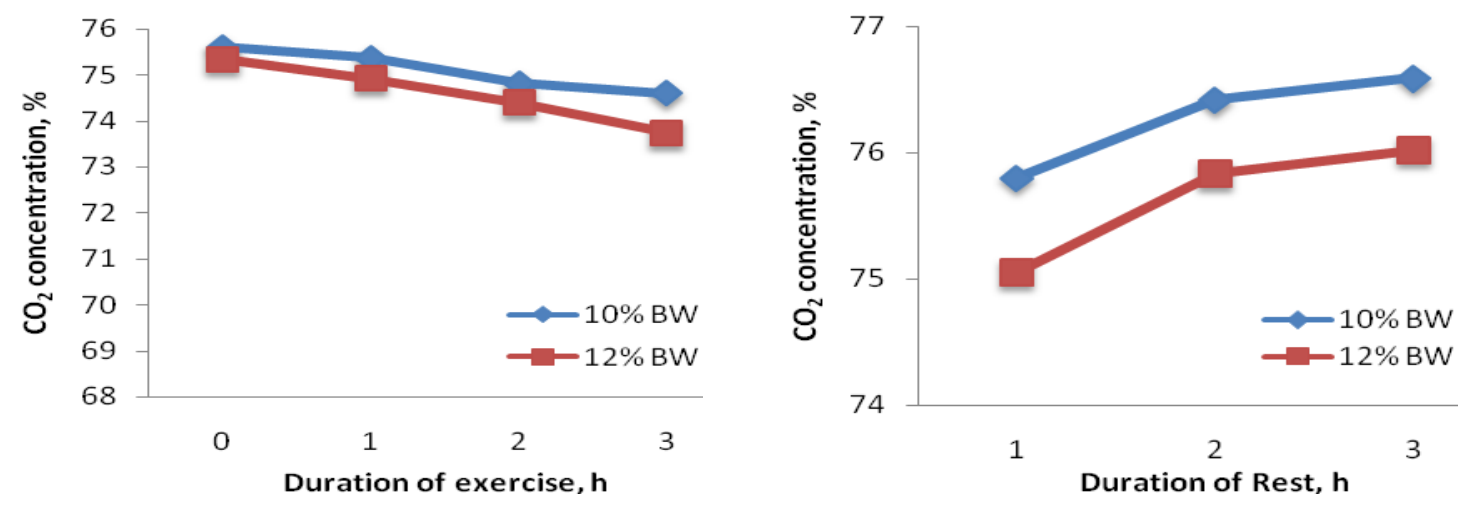

Fig.3.5 Carbon dioxide emission at 10\% draught level and different feed proportions at exercise and rest period

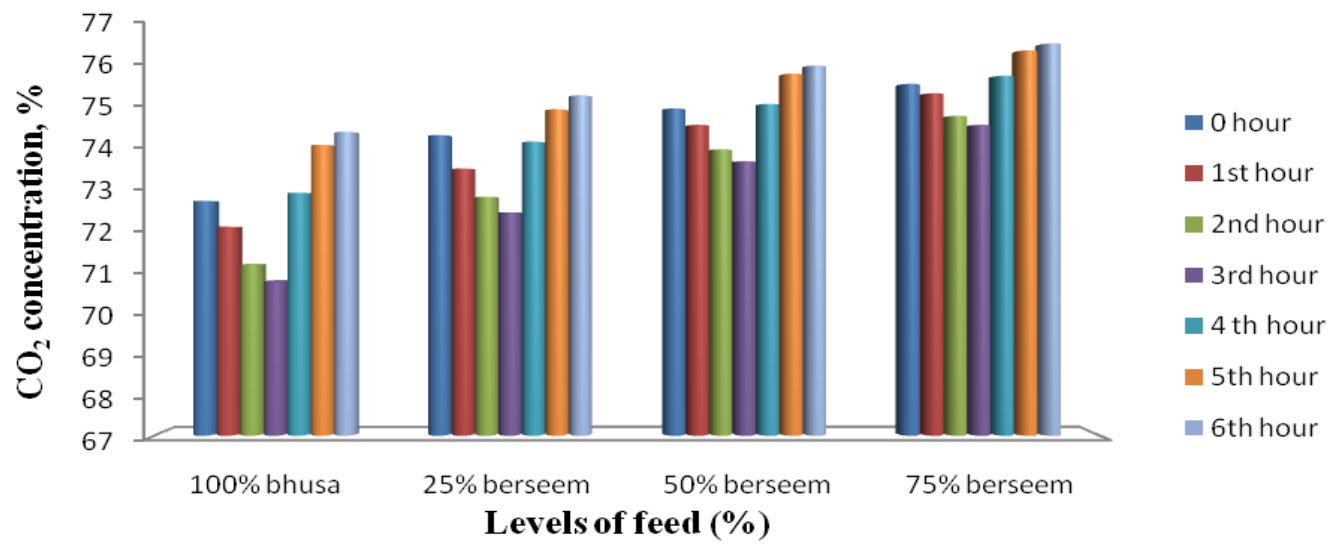

Fig.3.6 Carbon dioxide emission at 12\% draught level and different feed proportions at exercise and rest period

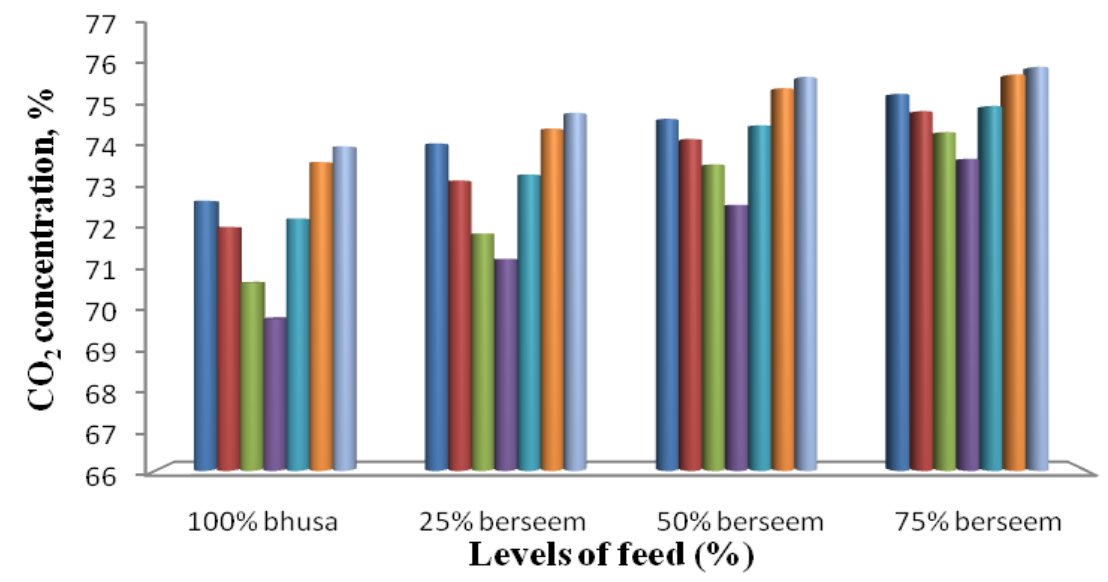

$$
\begin{aligned}
& \square 0 \text { hour } \\
& \square 1 \text { st hour } \\
& \square 2 \text { nd hour } \\
& \square 3 \text { rd hour } \\
& \square 4 \text { th hour } \\
& \square 5 \text { th hour } \\
& \square 6 \text { th hour }
\end{aligned}
$$


Fig.3.7 Effect of draught, feed, duration of rest on $\mathrm{CO}_{2}$ emission

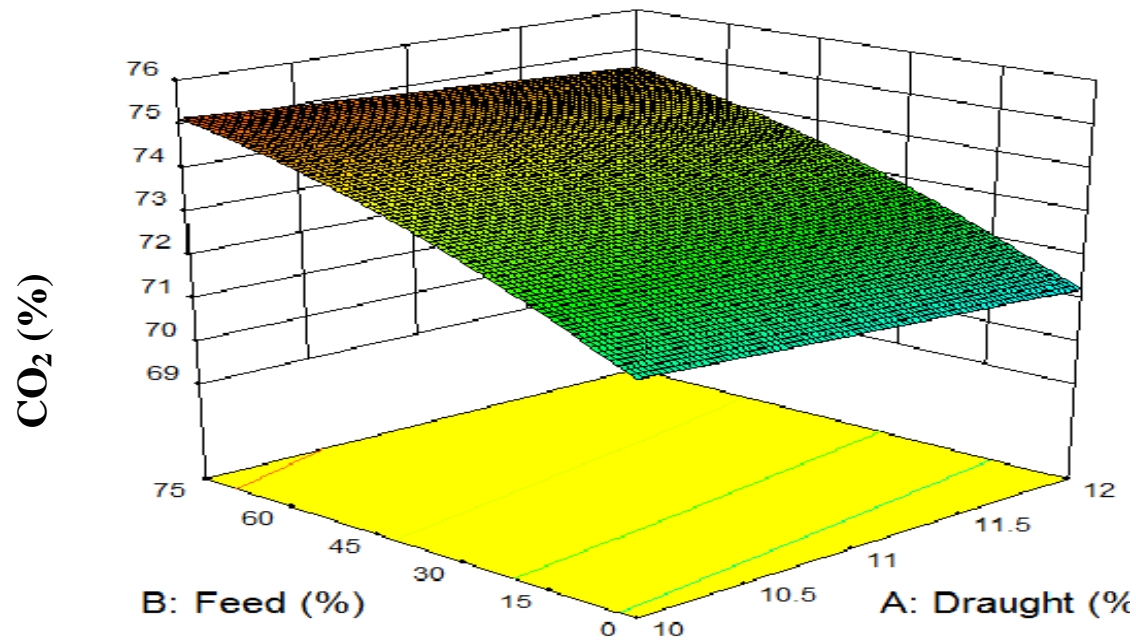

Fig.3.8 Effect of draught, feed and duration of rest on $\mathrm{CO}_{2}$ emission during rest

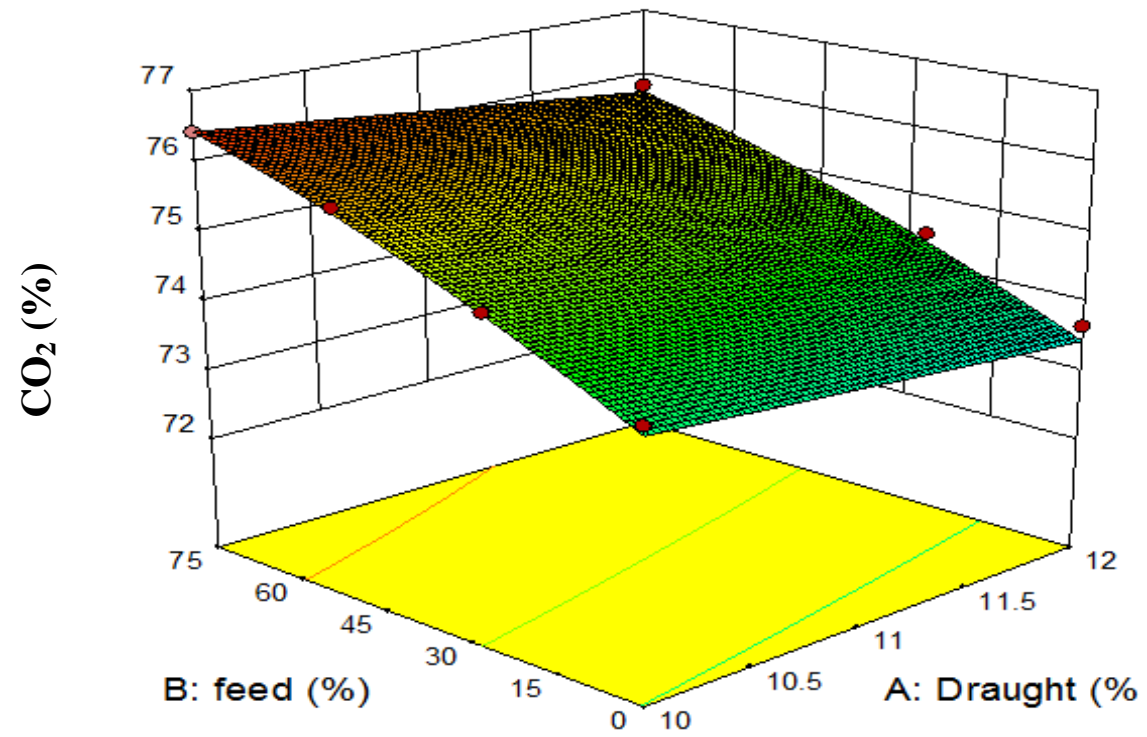

Conclusions of the study are as follows:

The dietary dependence has effect on the $\mathrm{CO}_{2}$ emission. It shows increasing trend with the increase of berseem percentage in feed.

The $\mathrm{CO}_{2}$ concentration in exhaled air of test he-buffalo shows decreasing trend with increase in duration of exercise and also with increase in level of draught
The maximum concentration of $\mathrm{CO}_{2}$ during exercise is $75.60 \%$ at $10 \%$ draught level and at $75 \%$ berseem on dry matter basis during initial hour (o h) of exercise.

$\mathrm{CO}_{2}$ concentration in exhaled gas was found increasing with the increase in duration of rest period after exercise. The maximum concentration of $\mathrm{CO}_{2}$ during rest was $76.59 \%$ at $10 \%$ draught level during $3^{\text {rd }}$ hour of rest 
and when $75 \%$ berseem on dry matter basis used during feeding.

\section{References}

$19^{\text {th }}$ Livestock census-All India Report 2012. Ministry of Agriculture, Department of Animal Husbandry and Fisheries.

Beauchemin, K. A., Eun J. S. 2008. Relationship between enzymic activities and in-vitro degradation of alfalfa hay and corn silage. Animal feed science and technology, 145 (14): 53-67.

Bell, M., Eckard, R., Moate, P. J., Yan, T. 2016. Modelling the effect of diet composition on enteric methane emissions across sheep, beef cattle and dairy cows. Multidisciplinary Digital Publishing Institute, 6(9): 54.

Kumar, m. and Nandini, N. 2015. Livestockrelated greenhouse gas emissions - a profile of Bengaluru urban district, India. International Journal of Advance Research, 3 (1): 290-295.

Madsen, J., Bjerg, B.S., Hvelplund, T., Weisbjerg, M. R. and Lund, P. 2010. Methane and carbon dioxide ratio in excreted air for quantification of the methane production from ruminants. Livestock Science, 129 : 223-227.

Mehadra, Jaiprakash. 2002. Effect of treadmill exercise and heat on physiology of male buffalo calves. Thesis M.V.Sc. (Animal Physiology),
Indian veterinary research InstituteDeemed University, Izatnagar (India). pp. 75.

Pedersen, S., Blanes-Vidal; Jørgensen, H,; Chwalibog, A., Haeussermann, A., Heetkamp, M.J.W., Aarnink, A.J.A., 2008. Carbon dioxide production in animal houses: a literature review. Agricultural Engineering International.: CGIR E journal: Manus BC 08 008, vol. X. December. 19 pp.

Pinares-Patino, C. S., D'Hour, P., Jouany, J. P. and Martin, C. 2006. Effects of stocking rate on methane and carbon dioxide emissions from grazing cattle. Agriculture, Ecosystems and Environment, $121: 30-46$.

Sniffen, C.J. and H. H. Herdt. 1991. Typical compositions of rumen gases. The Veterinary Clinics of North America: Food Animal Practice, Philadelphia, PA: W. B. Saunders Company, 7(2).

Sharma, S.C. 2006. Effect of environment and work conditions on fatigue of draught buffalo. Thesis, PhD. G.B. Pant University of Agriculture and Technology, Pantnagar.

Thakur, T.C., Singh., Bachchan and Singh, M. P. 1989b. Effect of load in physiological response of buffaloes in rotary mode. Agricultural Mechanization in Asia, Africa and Latin America, 20 (4): 15-22.

\section{How to cite this article:}

Akanksha, Jayant Singh and Singh, T.P. 2019. Effect of Feed and Draught on Carbon Dioxide Emission from the Rumen of He-Buffalo. Int.J.Curr.Microbiol.App.Sci. 8(04): 496-506. doi: https://doi.org/10.20546/ijcmas.2019.804.054 